\title{
22. Morphological Changes in Newt Epitheliomas caused by Controlled Temperature
}

\author{
By Makoto Asashima,*) Masumi Seki,*) Hiromi Kanno,*) \\ and Hiromichi KoYAMA**) \\ (Communicated by Kiyoshi TAKEWAKI, M. J. A., March 12, 1986)
}

Naturally occurring amphibian tumors are subject to geographic and seasonal fluctuations. In the frog, Rana pipiens, Lucké renal adenocarcinoma has been reported to occur in spring and autumn, but not in summer. ${ }^{6)}$ Moreover, the incidence of this tumor is restricted to the frogs from certain areas of Minnesota (U.S.A.). .7) Differences in geographical or local abundancy of papilloma or epithelioma in the Japanese newt, Cynops pyrrhogaster, have also been reported.2),4) The field prevalence of newt epitheliomas was high in autumn, but much lower in the rest of the year. These amphibian tumors were found to be associated with the presence of a virus.2),3),8),9)

One of the causative factors involved in the seasonal and geographical differences in tumor frequency in the field is temperature.4) This paper deals with the early morphological changes of epithelioma cells in the newt in response to experimental temperature conditions in the laboratory.

Materials and methods. Newts papillomas and temperature conditions: Of about 6500 specimens of the Japanese newts, Cynops pyrrhogaster, collected from the fields, ponds, and small creeks in Niigata and Iwate Prefectures in the autumn of 1982 and 1983, 271 newts $(=4.2 \%)$ with papillomas were found. These were separated from the rest and kept in the laboratory aquarium for 2 months at $13^{\circ} \mathrm{C}$. One-hundred and forty-four of the newts bearing tumors of $2.0-2.5 \mathrm{~mm}$ in diameter were divided into 4 groups of 36 each, and were exposed to different constant temperatures, $4^{\circ} \mathrm{C}$ (Group 1), $13^{\circ} \mathrm{C}$ (Group 2) and $30^{\circ} \mathrm{C}$ (Group 3), respectively. Group 4 (control) was kept under natural fluctuating temperature conditions. The newts were fed with freshwater oligochaetes (Tubifex hattai) throughout the experiment ${ }^{1)}$ and papilloma diameters were measured weekly in all of them.

Histological studies: Papillomas from 4 newts were fixed in Bouin's solution at $1,2,4,8,16$ and 30 weeks, embedded in paraffin, sectioned at $8 \mu \mathrm{m}$ and stained with Delafield's hematoxylin and eosin. The mitotic indices of papilloma cells were estimated on the basis of at least 1000 nuclei counted in each section.

Results. The normal skin of the control newts consisted of three cell layers. The surface epidermal layer was 2 to 3 cells thick. At the bottom of the epidermis, there was a concentrated melanin pigment layer under which the dermis was situated.

$4^{\circ} \mathrm{C}$ : After 8-week exposure to $4^{\circ} \mathrm{C}$, epitheliomas appeared to be regressive (Fig. 1). A large number of pycnotic or condensed nuclei occurred between the epidermis and dermis (Fig. 2a). In some histological sections, down-growths

*) Department of Biology, Yokohama City University, 22-2 Seto, Kanazawa-ku, Yokohama 236.

**) Second Anatomy, Faculty of Medicine, Yokohama City University, Urafune, Minami-ku, Yokohama 232. 


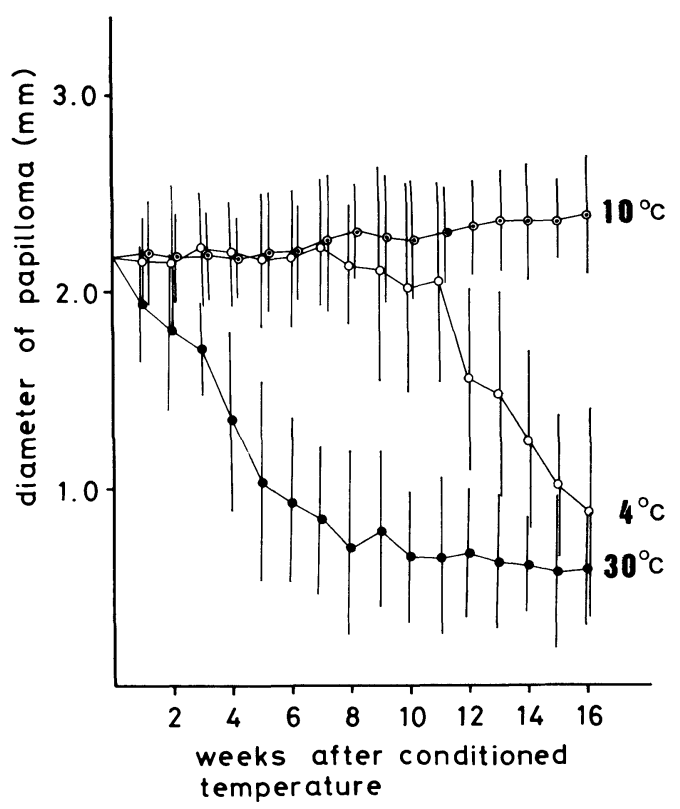

Fig. 1. Changes in diameters of newt papillomas at different temperatures: $\bigcirc, 4^{\circ} \mathrm{C} ; \odot, 10^{\circ} \mathrm{C} ; \bullet, 30^{\circ} \mathrm{C}$. Bars: S.E.
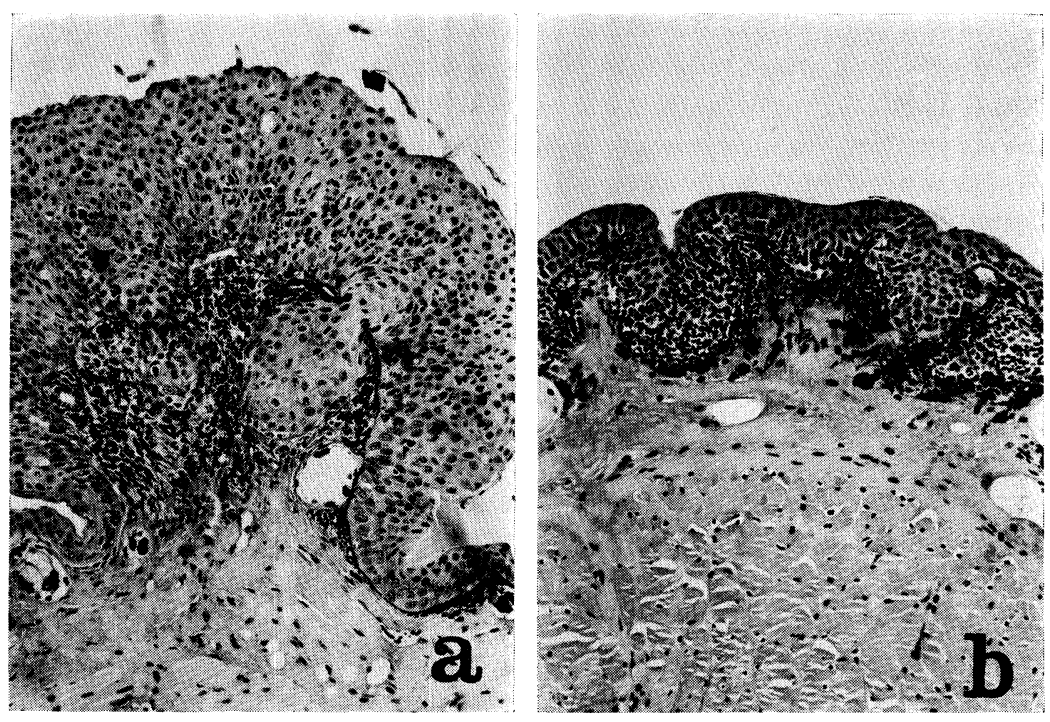

Fig. 2. Epithelioma after low $\left(4^{\circ} \mathrm{C}\right)$ and high $\left(30^{\circ} \mathrm{C}\right)$ temperature treatments. a: $4^{\circ} \mathrm{C}$ treatment; down-growth of epidermal cells and necrotic cells are seen near the dermis. $\mathrm{b}: 30^{\circ} \mathrm{C}$ treatment; necrotic cells are seen.

consisting of epidermal cells were visible. The basement membrane was well preserved (Fig. 2a). The mitotic indices fell to 0.27 within 2 weeks. After 4 weeks, the indices were still lower, varying from 0.23 to 0.10 (Fig. 3). 


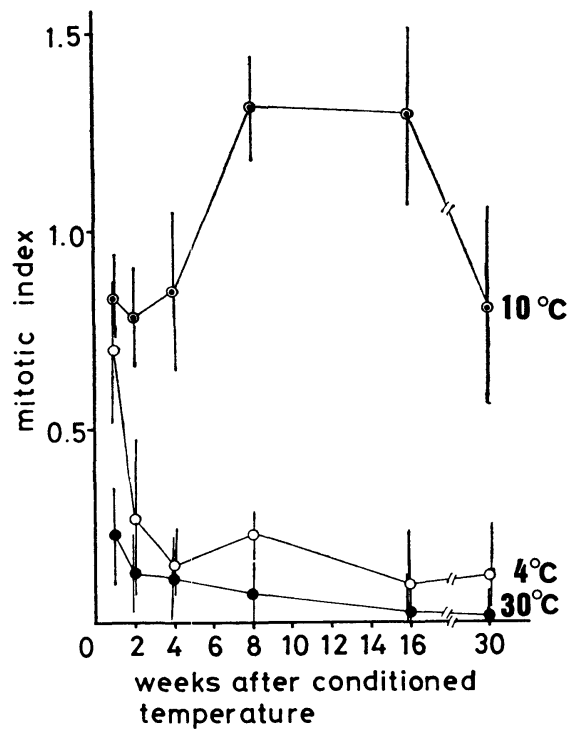

Fig. 3. Changes of mitotic indices of epithelioma cells after temperature treatments: $\bigcirc, 4^{\circ} \mathrm{C} ; \odot, 10^{\circ} \mathrm{C} ; \bullet, 30^{\circ} \mathrm{C}$. Bars: S.E.

$10^{\circ} \mathrm{C}$ : Nuclei of epithelioma cells in the animals kept at $10^{\circ} \mathrm{C}$ became larger than in the control as well as low temperature-animals $\left(4^{\circ} \mathrm{C}\right)$. In particular, nuclei of epithelioma cells near the basal layer were elongated and enlarged. In some cases, similar cells were often found toward the surface of the skin. Cells with signs of degeneration were not seen between the epidermis and dermis. The mitotic indices increased slightly by 4 weeks and at 6 weeks they increased still further (Fig. 3). The epithelioma increased gradually in diameter after 4 weeks (Fig. 1).

$30^{\circ} \mathrm{C}$ : Epithelioma disappeared, the overlying skin becoming flattened. Histclogical studies revealed no evidence for obvious cell migration. The mitotic indices underwent a sharp drop within a week and continued to be about 0.12 throughout the experimental period of 16 weeks (Fig. 3). Some epithelioma cells undergoing necrosis were observed near the pigment layer (Fig. 2b).

Discussion. It has been reported that the growth of newt papilloma was affected by laboratory temperature conditions.4),5) In tumor-bearing newts kept at water temperatures varying from 10 to $13^{\circ} \mathrm{C}$, papillomas tended to grow, whereas at 25 and $30^{\circ} \mathrm{C}$ or at $4^{\circ} \mathrm{C}$, papillomas decreased in size.

In a previous paper, ${ }^{4)}$ changes in size of papilloma cells in a 30 -week period were dealt with. In the experiments reported in the present paper demonstrated that the effects of temperature became evident much earlier. The mitotic index was strongly affected within as early as one week after the onset of temperature treatment. In the newts kept at $4^{\circ} \mathrm{C}$ or $30^{\circ} \mathrm{C}$, the mitotic indices remained low (0.03-0.27) throughout the experimental periods, whereas under mild temperature conditions $\left(10^{\circ} \mathrm{C}\right)$, the mitotic index of papilloma cells became significantly higher than at other temperatures. It is evident that the mitotic indices are closely related to the size of the newt papilloma. 
Acknowledgements. We are grateful to Professor T. Mizuno of the University of Tokyo for helpful suggestions and continuous interest. This work was supported in part by a Grant-in-Aid for Cancer Research from the Ministry of Education, Science and Culture of Japan.

\section{References}

1) Asashima, M., and S. Komazaki: Proc. Japan Acad., 56B, 638-642 (1980).

2) Asashima, M. et al.: Cancer Research, 42, 3741-3746 (1982).

3) Asashima, M., and T. Oinuma: J. Fac. Sci. Univ. Tokyo, sec. IV, 15, 151-158 (1982).

4) Asashima, M. et al.: Cancer Research, 45, 1198-1205 (1985).

5) Dickson, J. A., and D. E. Muckle: ibid., 32, 1916-1923 (1972).

6) McKinnell, R. G., and B. K. McKinnell: ibid., 28, 440-444 (1968).

7) McKinnell, R. G.: Biology of Amphibian Tumors (ed. M. Mizell). New York, Springer-Verlag, pp. 254-260 (1969).

8) Mizell, M.: ibid., pp.1-25 (1969).

9) Mizell, M., Stackpole, C. W., and S. Halperen: Proc. Soc. Exp. Biol. Med., 127, 96-98 (1968). 